\title{
É POSSÍVEL A SUBJETIVIDADE RESISTIR AO MARKETING DA EDUCAÇÃO E DA POLÍTICA?
}

\author{
ES POSIBLE LA SUBJETIVIDAD RESISTIR AL MARKETING DE LA \\ EDUCACIÓN Y DE LA POLÍTICA? \\ SUBJECTIVITY CAN RESIST TO EDUCATION AND POLITICS \\ MARKETING?
}

http://dx.doi.org/10.1590/1807-0310/2017v29152232

Flávia Cristina Silveira Lemos, Ellen Aguiar da Silva, Feliciana Ueyama e Marilda Couto

Universidade Federal do Pará, Belém/PA, Brasil

\begin{abstract}
RESUMO
O presente artigo aborda a produção de subjetividades, baseada nas imagens, no marketing, na política educativa, pautada em uma economia neoliberal. O controle social pela comunicação e informação atua pela rapidez e fluxo de imagens, a interatividade e o jogo veloz, na política instrumental do mercado. O artigo está construído a partir de táticas analíticas com os autores: Deleuze, Guattari, Arendt, Levy, Foucault e Virílio. Se a vigilância da captura e distribuição das imagens é ampliada e parece ser incontornável, as resistências podem ser realizadas pela tentativa de criações clandestinas, fugas à visibilidade constante, à velocidade da política e ao mercado da educação. Assim, a criação pode operar pelos mecanismos dos deslocamentos das subjetividades utilitaristas e controladas pela opinião. Criticar a capitalização e o empreendedorismo visual-auditivo permanente face à sociedade da informação e da comunicação instantâneas permite fabular uma problematização do presente.
\end{abstract}

Palavras-chave: subjetividades e imagens; educação; marketing; resistências.

\section{RESUMEN}

Este artículo discute la producción de subjetividad, en base a las imágenes, en la comercialización, la política educativa, basada en una economía neoliberal. El control social mediante la comunicación y la información opera la velocidad y el flujo de imágenes, la interactividad y la política de mercado instrumental. El artículo se construye a partir de las tácticas analíticos con autores: Deleuze, Guattari, Arendt, Levy, Foucault y Virílio. La vigilancia de la captura y distribución de imágenes se agranda y parece ser inevitable, las resistencias se pueden realizar al tratar de creaciones clandestinas, la visibilidad constante, la velocidad de la política y el mercado de la educación. La creación puede operar los mecanismos de desplazamiento de subjetividades, utilitarias y controlado por la opinión. Criticar la capitalización y el espíritu empresarial-visual y auditivo debido a la información instantánea de la empresa y la comunicación permite fábula una investigación sobre el presente.

Palabras clave: subjetividad e imágenes; educación; comercialización; resistencias.

\begin{abstract}
This article discusses the production of subjectivity based on images, marketing and educational policy in a neoliberal economy. The social control using communication and information operates through speed, flow of images, and interactivity: the instrumental market policy. The article is built from analytical tactics by authors such as Deleuze, Guattari, Arendt, Levy, Foucault and Virílio. If the surveillance of the images captured and distributed is on a large scale and appears to be inevitable, resistance can be performed through clandestine creations, and thus, escape from the constant visibility, the speed of politics and the education market. Thus, creation can operate trough the mechanisms of displacements of utilitarian subjectivities and controlled by opinion. Criticize the capitalization and permanent visual-auditory entrepreneurship due to the company's instant information and communication allows a fictional questioning of this subject, as well as inquire what are we doing to ourselves and others.
\end{abstract}

Keywords: subjectivity and images; education; marketing; resistances. 


\section{Introdução}

Este artigo é um ensaio teórico, visando a interrogar a busca de visibilidade exacerbada, nas últimas décadas, a partir da reprodução de imagens de si e dos outros como forma de governo das condutas, no cotidiano, impactando nas intervenções políticas, econômicas, sociais, culturais, familiares, trabalhistas, históricas e na formação de subjetividades.

O controle social e a vigilância passaram a ser mais intensivos na racionalidade imagética, e o marketing ganhou um estatuto de saber e poder diferenciado, juntamente com a economia política, nesse cenário. A circulação segura seria acompanhada de vigilância constante, monitorada por filmadoras, celulares, censores, documentos de identificação, senhas, satélites e avaliações permanentes (Lévy, 2004).

A lógica imagética tem atravessado diferentes espaços e equipamentos, corpos e práticas contemporâneas, tais como: a educação e o trabalho, os quais ganharam um lugar privilegiado no campo do capital imaterial, em termos de criação de visibilidades e dizibilidades do empreendedorismo neoliberal. Emerge uma sociedade passível de forjar pelo marketing a vida e tudo que lhe concerne, culturalmente, socialmente, afetivamente e no âmbito político-econômico.

A venda permanente de imagens sucessivas, capitalizadas e colocadas no mercado, tem alimentado as campanhas políticas de candidatos aos cargos dos Poderes Executivo e Legislativo; tem expandido o setor de vendas de objetos pelas marcas e embalagens; tudo com base na construção dos perfis pessoais, alvos a serem imitados por serem classificados como marcadores de sucesso. Portanto, modelos copiados e venerados supostamente são os efeitos da produção do mercado das imagens.

Assim, o marqueteiro ganhou um lugar privilegiado no chamado mercado empreendedor, articulando corpos/empresas como relações empresariais, em cada mínimo ato cotidiano. As marcas se tornaram mais importantes que os produtos vendidos, na disputa de mercados e na concorrência entre empresas (Deleuze, 1992). A contratação de funcionários e os estilos de vida dos trabalhadores e estudantes passaram a ser parte de uma produção de imagens a comercializar.

Assim, este artigo tem o objetivo de interrogar as relações constituídas entre marketing, subjetividade, educação e política, no presente. Busca-se nas ferramentas analíticas de Deleuze, Guattari, Virílio,
Arendt e Foucault um suporte para questionar a produção histórica das subjetividades imagéticas, das empresas como marcas a zelar e a construir, a educação empresarial como vetor de ensino para a capitalização do ser e a política reduzida aos perfis construídos pelo marketing, aplicado ao cotidiano das existências.

\section{Comunicação e produção do marketing empresarial de si e dos outros}

Foucault (2008a) declara que fazer circular é um efeito das práticas neoliberais da fabricação de subjetividades capturadas pelos mecanismos produtivos das vigilâncias por meio do efeito de visibilidade contemporâneo, em contextos democráticos da participação, do reconhecimento social pela explicitação do governo das condutas pelas imagens. Os bens, pessoas, saberes, alimentos e valores precisariam circular com segurança, e as barreiras seriam colocadas entre os que podem circular para consumir e realizar investimentos e os que não podem e comprometem a segurança dos empreendedores e consumidores.

Foucault (1999) assinala que os guetos e segregações são efeitos de um regime de separação dos que podem circular daqueles impedidos de fazê-lo por serem classificados como perigosos. A segurança seria a possibilidade de funcionamento da imagem dos que consomem e investem face aos que operam a imagem pela insegurança e falta de acesso, portanto pela discriminação negativa sofrida diariamente.

A discriminação é analisada por Castel (2008), ao destacar o quanto os autóctones da República foram fabricados pela imagem negativa dos inseguros e dos que tornam a vida de uma população insegura também. Assim, são definidos os grupos discriminados negativamente como supostos portadores de imagens marcadas pelo estigma do risco e perigo.

Em geral, os rótulos caracterizam os corpos e os lugares de moradia, condições de vida, relações de parentesco e comunidade próxima como potencialmente atravessada por fatores de risco, variando em intensidade até a classificação de perigosa (Castel, 1987). As situações de violência, desastre, crimes e adoecimentos, por exemplo, são mapeadas espacialmente, em termos de cálculos de risco e perigo.

A estatística de maior incidência probabilística de algum acontecimento faz uma região ser demarcada como zona de risco, área vermelha e, até mesmo, lugar visto como perigoso. As avaliações dos especialistas e peritos para examinar a condição de vida de cada grupo, 
comunidade e espaço são realizadas por um conjunto de variáveis delimitadas pelo desvio de normas e leis.

Assim, vigiar e criar visibilidade, além de promover imagens empresariais, também define táticas de controle social, na política pública, justificado por encomendas, tais como: realização de denúncias, proteção social pela detecção precoce das doenças, prazer de visualizar a vida dos outros, prevenir as mais variadas formas de violência. Observar e avaliar o que se passa com alguém face às normas sociais implica examinar pelo olhar, se referindo às imagens enquanto modelos de uma suposta condição de autonomia dos pares (Rose, 2011).

Uma expansão exorbitante dos mecanismos de vigilância se materializa e passa a mediar um modo de existência balizado pela sensação de que se está sendo olhado o tempo todo. Por isso, seria supostamente relevante criar imagens, tais quais kits de subjetividade, disponibilizados permanentemente (Rolnik, 1997).

Guattari e Rolnik (1996) salientam, nesse sentido, como a cultura tem funcionado enquanto dispositivo de equivalência de mais-valia subjetiva, no capitalismo mundial integrado, ao conectar todos os corpos e objetos pelo signo do capital, agenciando vetores de captura do desejo e até mesmo das resistências. Um exemplo é o comércio de roupas com imagens de líderes de revoluções, pesquisadores, artistas, educadores, tais como: Che Guevara, Nelson Mandela, Bob Marley, entre outros.

No curso Nascimento da Biopolítica, Foucault (2008b) assinalou a transformação da educação em empresa e investimento, calculado pelos custos e benefícios. O cálculo é permanente nas compensações e prejuízos dos contratos realizados e a concretizar, seja no plano das relações trabalhistas, seja no campo da amizade e conjugalidade. Tudo é transformado em investimento e empreendimento. Até mesmo as emoções e os afetos mais intensos se tornaram um negócio lucrativo ou não, dependendo das avaliações e dos contratos estabelecidos.

Segundo Ilhouz (2011), o amor é capitalizado e o cuidado das imagens de si delineadas pela saúde e normalidade, em prol da vertente psicológica da política da informação instantânea e veloz de divulgação do que se supõe ser sucesso, nessa sociedade individualista, competitiva e hedonista. Uma tônica da economia neoliberal é mediada pela contabilidade, atravessando a gestão de si e dos outros, efetuando os custos e os benefícios de cada escolha realizada (Foucault, 2008b).

Essas práticas ensejam uma maneira de a sociabilidade ganhar aspectos securitários pelo nível de transparência e controle dos acontecimentos aos olhares que tudo podem ver e gerir. Nesse âmbito, as práticas de vigilância passam a ser comercializadas, trocadas e apropriadas pelos dispositivos de segurança, empreendidos como politicamente relevantes para o neoliberalismo e economicamente rentáveis, no mercado da seguridade social (Castel, 1987).

Os sonhos, sentimentos, projetos e conhecimentos passam a ser comercializados pela propaganda e publicidade, no mercado das marcas, o qual forja a ilusão de ter sucesso e ser aceito (Flusser, 2008). O produto vendido incorpora a imagem da empresa e visa a ofertar objetos tais quais kits a vestir para agenciar prestígio e competência investimento.

A flexibilidade das imagens deve ser grande em termos da disponibilidade de deixar e construir novos projetos, conforme as encomendas recebidas, no mercado das marcas. A ética da criação e resistência cede lugar ao desgaste da repetição e ressentimento pelo que se foi e pelo que ainda não veio, dando lugar ao medo e à angústia face ao esboço mínimo de qualquer movimento disruptivo (Rolnik, 1997).

Por isso, Sodré (2010) destaca a formação de subjetividades, pautada pela imagem; sobretudo quando essa é concretizada pelas denominadas elites logotécnicas que visam a lucrar com a produção de subjetividades difundidas e valorizadas social e politicamente. Com efeito, é nesse âmbito que a paisagem foi constituída como uma maneira de olhar e enquadrar as imagens, fazendo-as ideais a serem imitados e vendidos como estilos de existências ditos de sucesso e mérito.

A paisagem é fabricada como caricatura e maquiagem de algo que seria menos interessante ou nem tão almejado se não estivesse construído como outdoor, fotos, cartão postal, perfil etc. Uma visão considerada bela para os olhares é vendida como paisagem no turismo e valorizada para o mercado imobiliário, por exemplo. Um lugar também é bastante visitado e almejado, quando é frequentado por pessoas classificadas como bonitas em certo estereótipo e bem vestidas, a partir de alguns critérios da indústria de massa do consumo (Sennett, 2003).

Assim, Garcia (2004, p. 45) ressalta o quanto "o produto perdeu importância para a marca, e é ela que define, na contemporaneidade, as estratégias de marketing". Aprender e ensinar entram em uma maquinaria do mercado e da competição constantes, alimentando e sendo alimentados pela voracidade de ascender ao chamado lugar de sucesso.

Esse lugar ganha dimensões de fetiche, obtido pela construção de imagens rentáveis no mercado 
das informações e na capitalização dos estilos de existência. Lazzarato e Negri (2013) denominaram essa prática de trabalho imaterial, a qual se efetua como uma capitalização do estilo de viver no contemporâneo. Deleuze afirma que a filosofia sempre teve muitos rivais.

$\mathrm{Na}$ atualidade, esses rivais são a informática, a comunicação e a promoção do comércio, visibilidade dos investimentos em imagens empresariais, disponibilizadas em formato de marketing como novo dispositivo de controle social. "A empresa é uma alma, um gás" (Deleuze, 1992, p. 221). Cada vez mais a empresa terceiriza a produção e investe na imagem da marca para vender serviços pela valorização, baseada em técnicas de marketing.

Virílio (2008) ressalta o quanto as imagens ganharam um lugar de destaque na sociedade atual, chegando a configurar um imperativo audiovisual a ser expandido ao nível do quase instante mesmo em que tenha ocorrido a fabricação do acontecimento. A velocidade da formação de espaços de visibilidades é a disputa pelo tempo em que as imagens são divulgadas e veiculam serviços.

A vida é racionalizada pela égide dos investimentos feitos e os resultados desses, em termos de agilidade na distribuição das imagens. A competição e a concorrência são termômetros da velocidade da difusão imagética, no formato da veiculação massiva das marcas, atreladas aos estilos de existência classificados como de sucesso. Ser visível é funcionar como uma empresa ao ponto de efetuar investimentos sucessivos, sem perder qualquer oportunidade de negociar algo.

Na produção frequente das imagens, a informática entra em uma relação com a quase instantaneidade das informações, do compartilhamento, da interação e da capitalização empresarial dos estilos de vida (Lazzarato \& Negri, 2013). Dessa forma, há uma captura das relações sociais, educativas, políticas, econômicas, culturais e afetivas pelas máquinas de visibilidade e vigilância a todo o momento.

Um novo capital social e cultural opera na distribuição e apropriação da rapidez, do fluxo e difusão das marcas e de seu agenciamento com a racionalidade imagética fabricada, adquirida e vendida no mercado das subjetividades. A velocidade da política efetua-se por uma economia neoliberal e por tecnologias de controle social e técnico das imagens (Virílio, 2008).

As imagens do espaço, do corpo, do bairro, da vestimenta, da comunidade, da cidade, da região e do país se tornaram acopladas ao capital do conhecimento e ao empreendedorismo cultural entrando nas engrenagens neoliberais. Os estudantes e trabalhadores são chamados a se constituírem como empreendedores, nessa racionalidade empresarial, segundo Foucault (2008b).

A formação das redes sociais, de relacionamentos afetivos e de trabalho, dos grupos para realizar trabalhos remunerados pelas práticas educativas passou, assim, também a ser mediada pela racionalidade imagética, informacional, da propaganda e do mercado das emoções e relacionamentos.

Nenhuma amizade, nenhum casamento ou contrato de trabalho escapa ao cálculo de custo e benefício do risco e perigo de estabelecer a relação e da avaliação dos efeitos, de lucros e prejuízos trazidos aos que se expõem a vivenciar experiências afetivas (Ilhouz, 2011). O desafio cada vez mais difícil e árduo, hoje, é resistir a essa parafernália social, técnica e político-econômica.

Bauman (2004) ressalta, em $O$ amor líquido, a expansão da fragilidade e pouca consistência dos relacionamentos de amizade, famílias, entre casais e pais e filhos, no presente. Superficiais e frágeis, sem compromisso e duração, os laços sociais e afetivos perdem confiança, sustentação e presença nas vidas. A insegurança cresce em intensidade e se espraia como vetor de subjetivação contemporânea.

O desamparo advindo dessa experiência da restrição dos laços sociais não é preenchido pela racionalidade imagética das redes sociais, na internet e nem pelas imagens difundidas de sucesso empreendedor. A alienação e o vazio dessa situação só aumentam, e o mercado das imagens, a venda de objetos com as insígnias das marcas e a frenética mutação do trabalho hoje não dão suporte suficiente à construção das subjetividades e ao estabelecimento das existências, nos planos ético, político e estético (Costa, 1997).

\section{Ser clandestino e se esconder para resistir ao marketing}

Escapar ao olho que tudo pretender ver como um ato de resistência, em que "a criação se faz em gargalos de estrangulamento ... Se um criador não é agarrado pelo pescoço por um conjunto de impossibilidades, não é um criador" (Deleuze, 1992, p. 167). É relevante criar vacúolos e espaços escuros para não ceder à ordem da sobrevivência em formato subjetividade/ empresa, a qual diminui a potência criativa. Conforme Caiafa (2000), o anonimato de um pseudônimo, por exemplo, auxilia a forjar passagens em meio aos 
perigos das capturas que a vigilância constante e a visibilidade contínua fabricam.

Pensar e problematizar a velocidade das imagens, a fabricação de subjetividades imagéticas, $o$ engendramento de marcas pela propaganda e o aprisionamento na posição de expectador é importante para resistir à captura da sociedade de controle e aos mecanismos de visibilidade permanente. A crítica é acionada como uma prática, uma atitude de avaliação do que é feito com os outros e do que faz de si.

Questionar a massiva produção de processos de homogeneização e cooptação dos corpos pela indústria cultural; criar uma problemática da dramática aceleração do tempo e das imagens, interrogar a empresa da educação instrumentalizada pelo sujeito da informação acumulada e capitalizada é um desafio, hoje.

Assim, tal qual Adorno (2002) destaca, faz-se relevante colocar em suspensão a publicidade, atrelada às artes, à educação, ao trabalho, às relações familiares e de amizade. Sair da esfera do entretenimento constante, do lazer-comércio do tempo livre e da cultura utilitária é parte das táticas do resistir à captura atual das experimentações existenciais.

Face às exigências de tudo ver e mostrar, resistir implica se transformar, transmutar-se, transfigurandose, tal qual o arlequim, em metamorfose e deslocamento. $\mathrm{O}$ arlequim é uma figura, a qual se veste de fantasias, tramas, narrativas, cores, não apenas na mutação do plano biológico de um se fazer outro, estranho a si e aos que o olham (Serres, 1993).

A resistência ganha o estranhamento do enquadramento das imagens e da problematização do que repete e aprisiona, produzindo certo atordoamento e náusea, dado o aspecto reprodutivo e tedioso da velocidade de imagens não pensadas e da convocação ao comércio permanente da figura do investidor e empreendedor incansável (Virílio, 2008).

O empresário não perde oportunidades de lucrar e ganhar com seus mínimos atos pontos na concorrência e competição, estabelecidas pelo estilo de vida neoliberal (Foucault, 2008b). Não desejar ser empresário e ganhar destaque é visto como anormalidade, hoje. Estar fora desse diagrama é sair de campo e deixar de existir praticamente.

Entretanto, resistir ao ver sem parar e ao deixar ser visível o tempo todo é possível, ao dissociar a imagem do tumulto da informação, conforme Caiafa (2003), para realizar um deslocamento subjetivo e a criação de modo a superar um consumo instantâneo e fazer ecoar a experimentação enquanto produção da diferença. Assim, para Deleuze (1992), resistir é tentar ser clandestino, decepcionar e não ficar acuado, afinal, se alegrar é melhor do que aceitar a cooptação política.

Conceder às encomendas de aprisionar-se na lógica imagética é da ordem da sobrevivência e causa diminuição da potência criativa, pois impede o inventar e reativa o ressentimento e o medo. Ora, é nesse campo existencial que se coloca a possibilidade de recusarse a virar vedete, se esconder e resistir à visibilidade em prol da problematização e efetuação das aberturas e passagens face às tentativas de tudo dar notícia e de tudo mostrar para todos verem (Deleuze, 1992).

A banalização das imagens em velocidade promove uma impossibilidade de criar e convida à passividade consumista (Arendt, 2013). No máximo, se traduz em investimento, capturado utilitariamente pela apropriação do capital humano. O empreendedorismo da informação e do empresariamento das imagens não cessa de tentar receptar e capturar o fôlego das resistências, tentando apagar a singularização dos acontecimentos.

Nesse aspecto, há de se colocar em xeque o modo de vida paisagem para conseguir criar lacunas e buracos por onde seja possível respirar não se mostrando para não ceder à sedução das imagens transmitidas, em seu fluxo interativo (Virílio, 2008). A paisagem é o que vemos como turistas, como empresários e consumistas. Diferente é a experimentação, pois resiste à imagem chapada e utilitária da cidade e dos corpos. A primeira tende à coisificação, e, a segunda, à singularização das existências. Finalizando, sair do estreitamento do encantamento imagético, tal qual narciso, fascinado, ao ver sua imagem no espelho, é conseguir instituir um estranhamento a ponto de resistir ao poder e à sedução da visibilidade constante.

Assim, ativar a potência da vida ganhou o estatuto de não apenas reagir como expectador à passividade tão comum ao tempo presente e passou a ser uma espécie de experiência devastadora de sofrer com a vigilância e a visibilidade em uma sociedade do exercício permanente de controle e marketing. A velocidade da política é um ingrediente para a urgência, a qual, por sua vez, desemboca nos fascismos e no tecnicismo sem possibilidade para diferir e desobedecer.

Desacelerar a velocidade das imagens, fazer algo durar e ganhar espessura de laço social e afetivo, cultivar um relacionamento sem fazê-lo limitar-se ao investimento econômico e funcional implicou constituir a criação sem perder o legado fabricado e sem abrir mão de tecer cuidados de si e dos outros. Um agenciamento do comum e do público é uma forma de resistir à paixão avassaladora por si mesmo e à avidez 
por uma busca do sucesso e da segurança técnica, impeditivas do experimentar e pensar (Dias, 2011).

Deleuze (2002) alertava que nem tudo que é bom para um é também bom para outrem. A experiência ética consiste na experimentação, e não na reprodução e cópia de um modelo de sucesso e supostamente de excelência a repetir. Os encontros são avaliados pela capacidade de ampliar e/ou reduzir a alegria de viver. Um termômetro para avaliar a si e a relação com os outros é a postura ética, possível apenas pela atitude crítica face ao presente.

Pensar por perguntas, colocar-se em deriva não é nada simples, porque os controles atuais operam rapidamente, em ondulação com forças centrífugas e centrípetas. Todavia, é possível criar estratégias de fuga à veloz rotação dos mecanismos de controle contemporâneos (Deleuze, 1992).

Até mesmo os movimentos sociais pedem proteções e reivindicam os direitos no plano da busca de reconhecimento e visibilidade. A pauta de tudo ver e do ser visto por todos nas lutas do presente cede à cooptação da vigilância democrática e da sedução das imagens instantâneas, constitutivas dos grupos sociais, das subjetividades e das relações.

\section{Considerações finais}

A velocidade técnica e social da produção e difusão das imagens, na atualidade, induziu ao crescimento de um vazio do girar em torno de si sem ocupar a cidade para também cuidar do outro. Houve um empobrecimento significativo do campo existencial face à redução da esfera pública, dos laços afetivos e sociais, paralelamente ao aumento exponencial do utilitarismo e à funcionalidade da segurança, tanto nos investimentos quanto na lógica empresarial.

O trabalho, a educação, a família, a amizade, o tempo livre, a visibilidade e o olhar foram apropriados pelo empreendedorismo via marketing e velocidade das redes sociais, sendo que, frente aos convites de capitalização de tudo, os relacionamentos foram esmagados pelo liberalismo utilitarista e por um mercado ávido pelo comércio de tudo e de todos. O sofrimento, os temores, as perdas, os prazeres, a iniciativa e a criação foram alvo de apropriação neoliberal, transformados em investimentos e lucro permanente.

O marketing e as tecnologias de controle social aumentam em importância, bem como as estratégias de vigilância simultâneas ao mercado das imagens, das marcas e da cultura instrumentalizada. Escapar a esses mecanismos e redes informacionais, lucrativas e securitárias se tornou um grande e difícil desafio do presente em que se vive.

Em tempos de um capitalismo de serviços, baseado na propaganda, publicidade e informação rápida em esvaziar as imagens, os controles finos e o mercado das relações é tecer um conjunto de práticas sociais, as quais podem auxiliar a criar linhas de fuga para forjar novos territórios de existência (Deleuze, 1992).

Cultivar a vida pública e não sucumbir à privatização de tudo passou a compor um esforço de problematizar os acontecimentos e experiências do processo de singularização contemporâneo (Sennett, 2003). Criar tempo para abrir-se ao compromisso, restringir imagens e esconder-se dos olhares que tudo querem saber e vigiar é importante para constituir vacúolos e entremeios, os quais permitam romper com as linhas duras e mover o diagrama de forças da sociedade (Deleuze, 2004).

Compor um estilo de existência como dispositivo afirmativo da vida é mais do que sucumbir à sobrevivência, em seu aspecto tedioso e acomodado, conformado e submetido ao mercado e à propaganda. Interroga-se, neste artigo, a vida gerida como uma empresa. Com efeito, diante do acontecimento subjetividade imagética, a produção da liberdade passa por esconder-se, por desacelerar o tempo e por esvaziar a condição de expectador e compartilhador de imagens rápidas.

Foucault (2010) assinala o quanto é rico refugiarse para pensar, afastar-se da frenética existência um pouco e tomar ar para retornar às lutas com a prudência de não ceder ao amor ao poder. A ética sucumbe ao fascismo quando nos apaixonamos pelo poder. A visibilidade contínua está nesse lugar de desejar ser venerado e reconhecido o tempo todo, estar em evidência constante.

O intolerável da imagem instantânea e da visibilidade transformada em vigilância foi alçado à condição de barreira a romper e a deslocar para outras composições de invenção das subjetividades. Para tanto, insistir em sacudir os modelos, pensar por problemas e perguntas ao invés de buscar soluções para as mesmas perguntas pode ser uma maneira de criar fôlego e ganhar força, coragem, alegria para agenciar uma política da vida e uma estética da existência (Deleuze, 2004).

Nesse plano de composição, busca-se um tornarse estrangeiro, mesmo em terra natal, e gaguejar na própria língua implica fazer brotar a diferença, na quebra da opacidade imagética e mercantil da propaganda. Poder esconder-se, desejar não ser vedete 
e fugir da vigilância securitária, bem como não querer fazer do cotidiano um investimento contínuo, é da ordem da resistência, em uma sociedade que exige visibilidade, segurança e imagens vigiadas (Deleuze, 2013).

\section{Referências}

Adorno, T. (2002). Indústria cultural e sociedade. São Paulo: Paz e Terra.

Arendt, H. (2013). Entre o passado e o futuro. São Paulo: Perspectiva.

Bauman, Z. (1999). Globalização: as consequências humanas. Rio de Janeiro: Zahar.

Bauman, Z. (2004). O amor líquido. Sobre a fragilidade dos laços humanos. Rio de Janeiro: Zahar.

Caiafa, J. (2000). Nosso século XXI: notas sobre arte, técnica e poderes. Rio de Janeiro: Relume Dumará.

Castel, R. (1987). A gestão de riscos: da antipsiquiatria à póspsicanálise. Rio de Janeiro: São Francisco.

Castel, R. (2008). Discriminação negativa: autóctones da República. Petrópolis, RJ: Vozes.

Costa, J. F. (1997). A ética democrática e seus inimigos. In E. P. Nascimento (Org.), Brasília: capital do debate. O século XXI - Ética (pp. 67-86). Rio de Janeiro; Brasília, DF: Garamond; Codeplan.

Deleuze, G. (1992). Conversações. Rio de Janeiro: Editora 34.

Deleuze, G. (2002). Espinosa. Filosofia prática. São Paulo: Escuta.

Deleuze, G. (2004). Diálogos. Lisboa: Relógio D’Água.

Deleuze, G. (2013). Crítica e clínica. Rio de Janeiro: Editora 34.

Dias, R. (2001). Nietzsche, vida como obra de arte. Rio de Janeiro: Civilização Brasileira.

Flusser, V. (2008). O universo das imagens técnicas. Elogio da superficialidade. São Paulo: AnnaBlume.

Foucault, M. (1999). Vigiar e punir: história da violência nas prisões. Petrópolis, RJ: Vozes.

Foucault, M. (2008a). Segurança, território e população. São Paulo: Martins Fontes.

Foucault, M. (2008b). Nascimento da biopolítica. São Paulo: Martins Fontes.

Foucault, M. (2010). Hermenêutica do sujeito. São Paulo: Martins Fontes.

Garcia, J. (2004). O negócio do social. Rio de Janeiro: Zahar.

Guattari, F. \& Rolnik, S. (1996). Micropolitica: cartografia do desejo. Petrópolis, RJ: Vozes.
Ilhouz, E. (2011). O amor nos tempos do capitalismo. Rio de Janeiro: Zahar.

Lazzarato, M. \& Negri, A. (2013). O trabalho imaterial. Rio de Janeiro: Lamparina.

Lévy, P. (2004). Tecnologias da inteligência. O futuro do pensamento na era da informática. Rio de Janeiro: Editora 34.

Rolnik, S. (1997). Toxicômanos de identidade. Subjetividade em tempo de globalização. In D. Lins (Org.), Cultura e subjetividade. Saberes nômades (pp. 19-24). Campinas, SP: Papirus.

Rose, N. (2011). Inventando nossos selfs. Petrópolis, RJ: Vozes. Sennett, R. (2003). A corrosão do caráter: consequências pessoais do trabalho no novo capitalismo. Rio de Janeiro; São Paulo: Record.

Serres, M. (1993). Filosofia mestiça. Rio de Janeiro: Nova Fronteira.

Sodré, M. (2010). O monopólio da fala: função e linguagem da televisão no Brasil. Petrópolis, RJ: Vozes.

Virílio, P. (2008). O espaço crítico. Rio de Janeiro: Editora 34.

Agência de fomento: $\mathrm{CNPq}-$ Processo 301823/2015-4.

Submissão em: 18/07/2015

Revisão em: 21/11/2015

Aceite em: 26/11/2015

Flávia Cristina Silveira Lemos é professora. Associada I de Psicologia Social Universidade Federal do Pará. Bolsista de Produtividade CNPQ-PQ2.

Endereço para correspondência: Avenida Augusto Côrrea, N. 01, IFCH-UFPA. Bairro: Guamá. Belém/PA, Brasil. CEP 66.000-000. E-mail: flavazevedo@hotmail.com

Ellen Aguiar da Silva é doutoranda em Educação Universidade Federal do Pará.

E-mail: ellenaguiardasilva@yahoo.com.br

Feliciana Ueyama é mestra em Psicologia Universidade Federal do Pará.

E-mail: felicianaueyama@gmail.com

Marilda Couto é psicóloga. E-mail: sitedocanto@yahoocom.br 